\title{
ANALISIS KADAR ASAM URAT PADA PENDERITA GAGAL GINJAL KRONIS (GGK)
}

\author{
Dewa Ayu Ratna Susanti \\ Universitas Pendidikan Ganesha \\ Singaraja, Indonesia \\ e-mail: ratna89@gmail.com
}

\begin{abstract}
Abstrak
Penelitian ini bertujuan untuk mengetahui (1) kadar asam urat pada penderita gagal ginjal kronis, (2) persentase penderita hiperurikimia dari pasien gagal ginjal kronis di RSUD Kabupaten Buleleng. Subyek penelitian ini adalah serum darah penderita gagal ginjal kronis yang ada di RSUD Kabupaten Buleleng. Obyek penelitian ini adalah kadar asam urat penderita gagal ginjal kronis yang memeriksakan diri di laboratorium RSUD Kabupaten Buleleng. Data tentang kadar asam urat penderita gagal ginjal kronis (GGK) dianalisis secara deskriptif. Dengan menggunakan kadar maksimum asam urat dalam tubuh $(8 \mathrm{mg} / \mathrm{dL})$ sebagai patokan, dicari rentangan kadar yang kurang dari $8 \mathrm{mg} / \mathrm{dL}$ dan rentangan kadar yang lebih dari $8 \mathrm{mg} / \mathrm{dL}$. Persentase penderita hiperurikimia pada GGK diperoleh dengan membandingkan jumlah penderita hiperurikimia terhadap seluruh penderita gagal ginjal kronis. Hasil penelitian menunjukkan, kadar asam urat penderita gagal ginjal kronis di RSUD Kabupaten Buleleng, ada pada rentangan 7,5-17.1 mg/dL. Penderita GGK yang kadar asam uratnya normal $(7,5-8,0$ $\mathrm{mg} / \mathrm{dL}$ ) sebanyak $15,79 \%$, sedangkan penderita GGK yang kadar asam uratnya melebihi kadar maksimum $(9,0-17,1 \mathrm{mg} / \mathrm{dL})$ sebanyak $84,21 \%$ yang merupakan penderita gagal ginjal kronis sekaligus menderita kelebihan asam urat (hiperurikimia).
\end{abstract}

Kata kunci: Asam urat, Gagal Ginjal Kronis

\section{Pendahuluan}

Asam urat atau uric acid dalam An Encyclopedia of Chemicals and Drugs, tahun 1997 dinyatakan sebagai suatu senyawa turunan purin. Senyawa yang pertama kali ditemukan oleh Schele pada tahun 1776 ini merupakan hasil akhir metabolisme purin (salah satu unsur protein) yang terbentuk di hati, selanjutnya dibawa ke ginjal melalui aliran darah. Ginjal yang sehat akan mengatur kadar asam urat dalam darah agar selalu dalam keadaan normal dengan mengeluarkannya bersama air seni, dimana kadar maksimum asam urat dalam darah adalah < $8 \mathrm{mg} / \mathrm{dL}$. Secara garis besar dapat dikatakan ada dua kondisi yang menyebabkan kadar asam urat tinggi dalam darah dan sampai menumpuk di jaringan sendi yaitu, kondisi organ tubuh normal namun produksi purin dalam tubuh berlebih, baik yang disebabkan oleh makanan maupun kerusakan sel-sel tubuh atau produksi purin dalam tubuh normal namun ada gangguan organ dalam seperti ginjal (Mathewes, 1991).

Gagal ginjal kronis (GGK) merupakan kerusakan ginjal yang tidak bisa disembuhkan kembali. Pada keadaan ini, hasil metabolisme purin (asam urat) yang seharusnya diekskresikan keluar tubuh melalui ginjal tidak terjadi, sehingga asam urat dalam darah semakin lama akan semakin menumpuk demikian pula dalam jaringan sendi. Kelebihan asam urat dalam darah inilah yang disebut hiperurikimia. Hiperurikimia sangat beresiko tinggi menyebabkan arthritis gout, yang merupakan penyakit yang menyerang sendi tangan dan kaki dengan gejala nyeri dan kaku. Siksaan nyeri dan pembengkakan tersebut membuat pasien sulit berjalan. Arthritis gout memang tidak mengancam jiwa, tetapi jika penyakit yang diakibatkan oleh kelebihan asam urat ini menyerang penderita dalam waktu yang lama, maka penderita bisa mengalami cacat persendian tangan dan kaki seumur hidup. Ini terjadi karena kristalisasi asam urat terbentuk pada persendian, jaringan di bawah kulit ( Rusbandi S, 2004).

Penderita gagal ginjal kronis jarang menghiraukan penumpukan asam urat dalam darahnya. Pasien umumnya hanya melakukan pengobatan pada ginjalnya, melalui haemodialisa (cuci darah), tanpa menyadari asam urat yang telah menumpuk dalam darahnya dapat menimbulkan arthritis gout.

Berdasarkan laporan tahunan yang didapat dari catatan rekam medik RSUD Kabupaten Buleleng, pada tahun 2004 penderita gagal ginjal kronis yang melakukan rawat inap dan rawat 
jalan sebanyak 153 orang yaitu $11 \%$ dari seluruh pasien yang melakukan perawatan di sana. Gagal ginjal kronis merupakan salah satu dari sepuluh penyakit yang sering diderita oleh masyarakat, dan juga. merupakan salah satu dari sepuluh penyakit yang sering menyebabkan kematian.

Rumah Sakit Umum Daerah Kabupaten Buleleng merupakan rumah sakit yang memiliki sarana penunjang berupa laboratorium patologi klinik. Salah satu kegiatan yang ada di laboratorium ini adalah memeriksa kadar asam urat dalam darah yang termasuk dalam pemeriksaan kimia klinik.

Berdasarkan uraian di atas, maka dilakukan penelitian untuk menjawab permasalahan sebagai berikut.

1. Berapakah kadar asam urat pada penderita gagal ginjal kronis di RSUD Kabupaten Buleleng?

2. Berapakah persentase penderita hiperurikimia dari pasien gagal ginjal kronis di RSUD Kabupaten Buleleng?

Tujuan yang mendasari dilaksanakannya penelitian ini adalah sebagai berikut.

1. Untuk mengetahui kadar asam urat pada penderita gagal ginjal kronis di RSUD Kabupaten Buleleng

2. Untuk mengetahui persentase penderita hiperurikimia dari pasien gagal ginjal kronis di RSUD Kabupaten Buleleng.

\section{Metode}

Penelitian Jenis penelitian ini adalah penelitian deskriptif, yang bertujuan untuk menggambarkan atau mendeskripsikan kadar asam urat pada penderita gagal ginjal kronis dan mendeskripsikan persentase penderita hiperurikimia pada penderita gagal ginjal kronis di RSUD Kabupaten Buleleng. Rancangan penelitian yang akan dilakukan disajikan dalam Gambar 1.

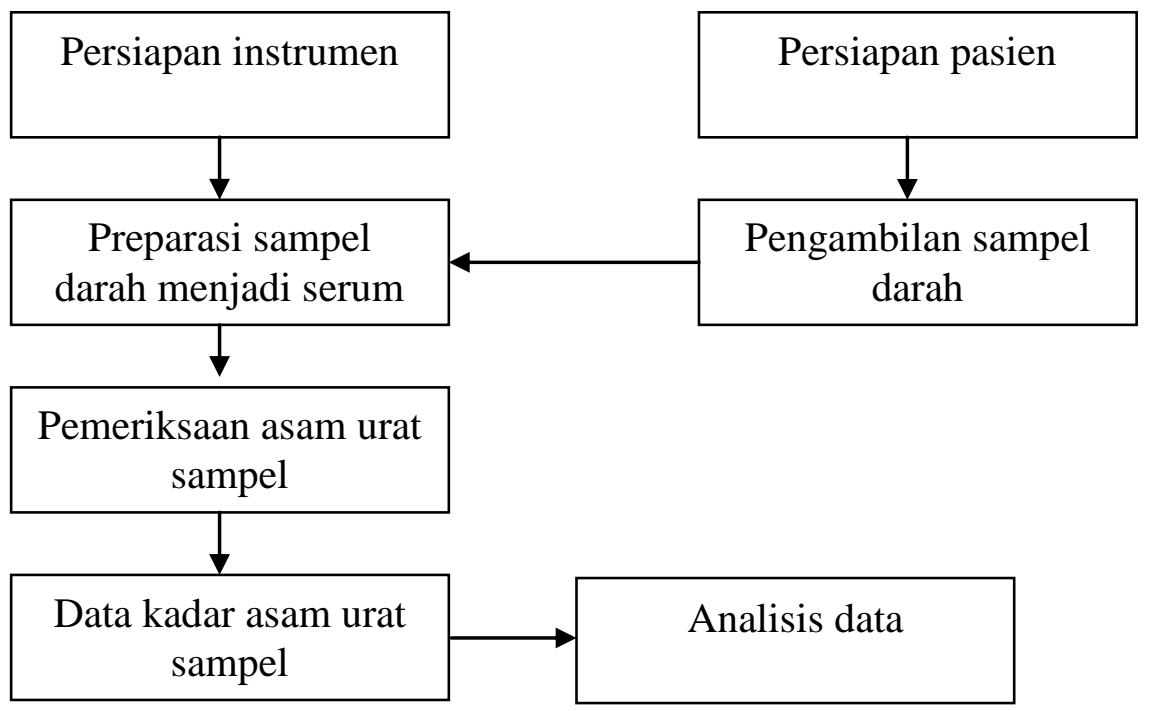

Gambar 1. Rancangan Penelitian

Penelitian ini diawali dengan persiapan pasien penderita gagal ginjal kronis dan persiapan instrumen. Dari bulan April 2005 sampai bulan Juni 2005 diambil sampel darah penderita gagal ginjal kronis di ruang sampling RSUD Kabupaten Buleleng. Seluruh sampel yang didapat dikumpulkan, dipreparasi menjadi serum dan diperiksa di laboratorium dengan menggunakan spektrofotometer BTS 310 pada panjang gelombang $546 \mathrm{~nm}$. Data kadar asam urat masing-masing penderita gagal ginjal kronis dikumpulkan sebagai data hasil penelitian. Dari seluruh data dicari rentangannya, kemudian dengan menggunakan kadar maksimum asam urat $8 \mathrm{mg} / \mathrm{dL}$ sebagai patokan (pembanding), dilakukan analisis secara deskriptif. Untuk mendapatkan persentase penderita hiperurikimia maka, jumlah penderita hiperurikimia dibandingkan dengan seluruh penderita gagal ginjal kronis. 


\section{Hasil dan Pembahasan}

Data hasil pemeriksaan kadar asam urat pada perderita GGK yang diperoleh dalam penelitian ini ditunjukkan pada Tabel 1.

Tabel 1. Data Hasil Pemeriksaan Kadar Asam Urat pada Penderita GGK di Rumah Sakit Umum Daerah Kabupaten Buleleng.

\begin{tabular}{cc}
\hline Subyek & Kadar Asam Urat $(\mathbf{m g} / \mathbf{d L})$ \\
\hline 1 & 13,0 \\
2 & 17,1 \\
3 & 7,9 \\
4 & 11,4 \\
5 & 10,8 \\
6 & 10,3 \\
7 & 10,7 \\
8 & 7,5 \\
9 & 12,9 \\
10 & 11,3 \\
11 & 10,6 \\
12 & 9,2 \\
13 & 16,4 \\
14 & 9,8 \\
15 & 16,2 \\
16 & 11,7 \\
17 & 8,0 \\
18 & 10,1 \\
19 & 9,0 \\
\hline
\end{tabular}

Dari data yang telah disampaikan, kadar asam urat penderita gagal ginjal kronis ada pada rentangan 7,5-17,1 $\mathrm{mg} / \mathrm{dL}$. Kemudian, dikelompokkan menjadi dua kelompok, yaitu kelompok untuk rentangan kadar asam urat 7,5 - 8,0 mg/dL sebanyak 3 orang, merupakan penderita gagal ginjal kronis dengan kadar asam urat normal. Kelompok untuk rentangan kadar asam urat penderita gagal ginjal kronis 9,0 - 17,1 sebanyak 16 orang, dimana kadar yang melebihi nilai normal ini disebut penderita hiperurikimia (kelebihan asam urat dalam tubuh).

Persentase penderita hiperurikimia dari 19 penderita gagal ginjal kronis yang memeriksakan kadar asam urat dalam darahnya, dapat dihitung menggunakan Persamaan 3.1

$$
\begin{aligned}
& \begin{aligned}
\% \text { penderita hiperurikimia } & =\frac{16}{19} X 100 \% \\
& =84,21 \%
\end{aligned} \\
& \begin{aligned}
\% \text { bukan penderita hiperurikimia, } 100 \%-84,21 \%=15,79 \%
\end{aligned}
\end{aligned}
$$

Dari hasil penelitian dapat diketahui bahwa, kadar asam urat penderita gagal ginjal kronis ada pada rentangan $7,5-17,1 \mathrm{mg} / \mathrm{dL}$. Rentangan kadar asam urat penderita gagal ginjal kronis $7,5-8,0 \mathrm{mg} / \mathrm{dL}$, merupakan rentangan kadar normal (rentangan kadar yang kurang dari 8 $\mathrm{mg} / \mathrm{dL}$ ) dan 9,0 - 17,1 $\mathrm{mg} / \mathrm{dL}$ yang merupakan rentangan kadar yang lebih dari $8 \mathrm{mg} / \mathrm{dL}$ (rentangan hiperurikimia). Kadar asam urat penderita gagal ginjal kronis yang normal, kemungkinan disebabkan oleh beberapa faktor yaitu, penderita gagal ginjal kronis tersebut melakukan diet rendah purin yang merupakan salah satu penghasil asam urat dalam tubuh atau penderita gagal ginjal kronis tersebut telah melakukan pengobatan terhadap penumpukan kadar asam urat dalam darahnya.

Kadar asam urat penderita gagal ginjal kronis, sebagian besar melebihi keadaan normal yaitu ada dalam rentangan $(9,0-17,1 \mathrm{mg} / \mathrm{dL})$. Keadaan inilah yang disebut hiperurikimia. Hiperurikimia sangat beresiko terhadap gangguan penyakit. Menumpuknya asam urat di jaringan sendi dengan membentuk kristal monosodium urat (MSU), dengan gejala yang 
dirasakan penderita adalah nyeri, kaku dan sakit yang luar biasa dapat menyebabkan cacat persendian seumur hidup. Keadaan asam urat yang tinggi ini kemungkinan disebabkan oleh keadaan ginjal yang tidak berfungsi dimana darah yang mengandung asam urat yang masuk ke ginjal tidak bisa disaring oleh glomerolus. Hal yang sama terjadi pada tubulus ginjal yang tidak mampu menyerap zat berguna dan mengeluarkan zat yang tidak berguna yang ada di darah. Akibatnya, darah kembali beredar ke seluruh tubuh dan akhirnya asam urat tidak mampu dikeluarkan oleh tubuh melalui urin. Sehingga apabila diiringi dengan asupan makanan yang mengandung purin tinggi, seperti kacang-kacangan, jeroan, hati, kadar asam urat akan tetap tinggi dalam darah dan menumpuk di jaringan sendi.

Langkah-langkah yang dapat dilakukan agar asam urat tidak semakin tinggi adalah dengan mengkonsumsi obat yang memiliki zat aktif alopurinol. Alopurinol dapat menghambat reaksi penguraian purin sampai terbentuknya asam urat yang terjadi karena adanya xantin oksidase. Xantin oksidase akan menghidroksilasi alopurinol menjadi aloxantin (oksipurinol), reaksi pembentukan oksipurinol disajikan pada Gambar 2.<smiles>Oc1ncnc2[nH]ncc12</smiles>

Alopurinol<smiles>Oc1nc(O)c2cn[nH]c2n1</smiles>

Oksipurinol

\section{Gambar 2. Reaksi Pembentukan Oksipurinol}

Demikian juga kecepatan biosintesis purin akan menurun karena alopurinol menyingkirkan PRPP (5'-fosforibosil-1-pirofosfat) dengan membentuk ribonukleotida alopurinol. Selanjutnya ribonukleotida alopurinol menghambat konversi PRPP menjadi fosforibosilamin, sehingga sintesis asam urat akan segera menurun setelah pemberian alopurinol.

Persentase penderita hiperurikimia dari pasien gagal ginjal kronis di RSUD Kabupaten Buleleng adalah $84,21 \%$. Nilai ini dapat dikatakan tinggi yang artinya seorang penderita gagal ginjal kronis kemungkinan akan menderita hiperurikimia yang sangat beresiko diserang beberapa penyakit lain, seperti arthritis gout, hipertensi, diabetes militus dan lain-lain.

\section{Simpulan dan Saran}

Dari Dari pembahasan yang telah disampaikan di atas dapat disimpulkan sebagai berikut.

1. Kadar asam urat penderita gagal ginjal kronis di RSUD Kabupaten Buleleng ada pada rentangan 7,5-17,1 $\mathrm{mg} / \mathrm{dL}$. Kadar asam urat normal penderita GGK ada dalam rentangan 7,5 - 8,0 mg/dL, sedangkan kadar asam urat penderita GGK yang melebihi kadar maksimum ada pada rentangan $9,0-17,1 \mathrm{mg} / \mathrm{dL}$, merupakan penderita gagal ginjal kronis yang sekaligus mengalami hiperurikimia.

2. Persentase penderita hiperurikimia dari penderita gagal ginjal kronis di RSUD Kabupaten Buleleng adalah $84,21 \%$.

Saran

Dari hasil penelitian ini saran yang dapat peneliti sampaikan adalah sebagai berikut.Bagi masyarakat yang didiagnosis menderita gagal ginjal kronis agar segera memeriksakan kadar asam urat dalam darahnya. Sehingga bila terjadi penumpukan asam urat dalam darah, bisa segera ditindaklanjuti untuk mencegah terjadinya hiperurikimia. 


\section{Daftar Pustaka}

Anderson, Price Sylvia dan Mecarty, Wilson Lorraine. 1990. Patologifisiologi Edisi 2 Bagian 2. Jakarta: Penerbit Buku Kedokteran EGC.

Basoeki, Soedjono. 1998. Anatomi dan Fisiologi Manusia. Jakarta: Depdikbud Direktorat Jendral Pendidikan Tinggi Proyek Pengembangan Bimbingan Pendidikan Tenaga Kependidikan.

Lumenta, Niko A. 1992. Penyakit Ginjal. Jakarta: Gunung Mulia

Marks, Dawn B. 1996. Biokimia Kedokteran Dasar. Jakarta: Penerbit Buku Kedokteran EGC.

Rusbandi, S. 2004. Asam Urat Penyebab Nyeri Pada Sendi. Cakrawala (hlm.5)

Widmann, Frances K. 1995. Tinjauan Klinis atas Hasil pemeriksaan Laboratorium Edisi 9. Jakarta: Penerbit Buku Kedokteran EGC.

Youngson, M R. 1996. Tubuh Manusia. Jakarta: Penerbit Arcan 